
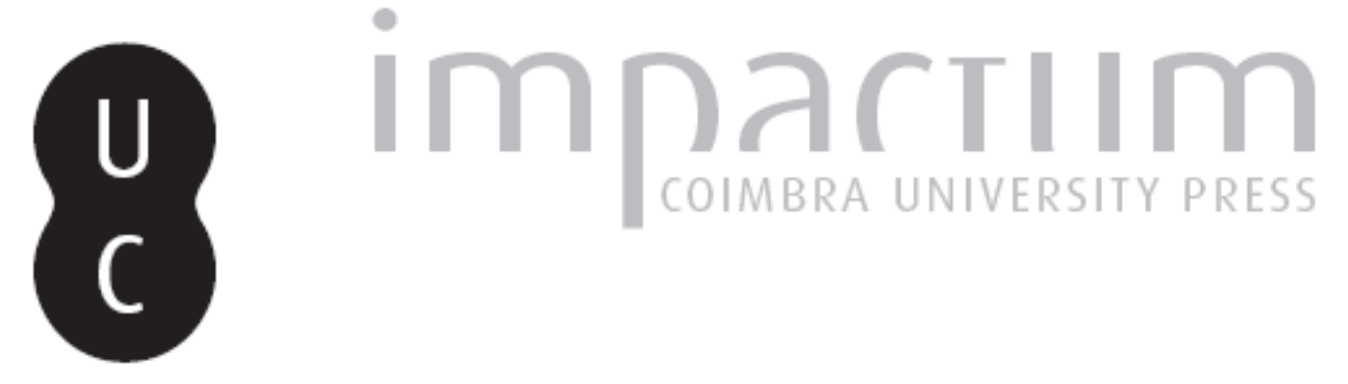

\title{
I connect, therefore I am!: places, locales, locations and informational territorialization
}

Autor(es): $\quad$ Lemos, André; Firmino, Rodrigo

Publicado por: Imprensa da Universidade de Coimbra

URL persistente:

URI:http://hdl.handle.net/10316.2/38250

DOI:

DOI:http://dx.doi.org/10.14195/1647-8622_15_1

Accessed : $\quad$ 26-Apr-2023 11:19:34

A navegação consulta e descarregamento dos títulos inseridos nas Bibliotecas Digitais UC Digitalis, UC Pombalina e UC Impactum, pressupõem a aceitação plena e sem reservas dos Termos e Condições de Uso destas Bibliotecas Digitais, disponíveis em https://digitalis.uc.pt/pt-pt/termos.

Conforme exposto nos referidos Termos e Condições de Uso, o descarregamento de títulos de acesso restrito requer uma licença válida de autorização devendo o utilizador aceder ao(s) documento(s) a partir de um endereço de IP da instituição detentora da supramencionada licença.

Ao utilizador é apenas permitido o descarregamento para uso pessoal, pelo que o emprego do(s) título(s) descarregado(s) para outro fim, designadamente comercial, carece de autorização do respetivo autor ou editor da obra.

Na medida em que todas as obras da UC Digitalis se encontram protegidas pelo Código do Direito de Autor e Direitos Conexos e demais legislação aplicável, toda a cópia, parcial ou total, deste documento, nos casos em que é legalmente admitida, deverá conter ou fazer-se acompanhar por este aviso.

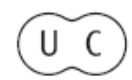




\section{comunicação, jornalismo e espaço público na era digital}

\section{ESTUD OSD OSÉCULO}

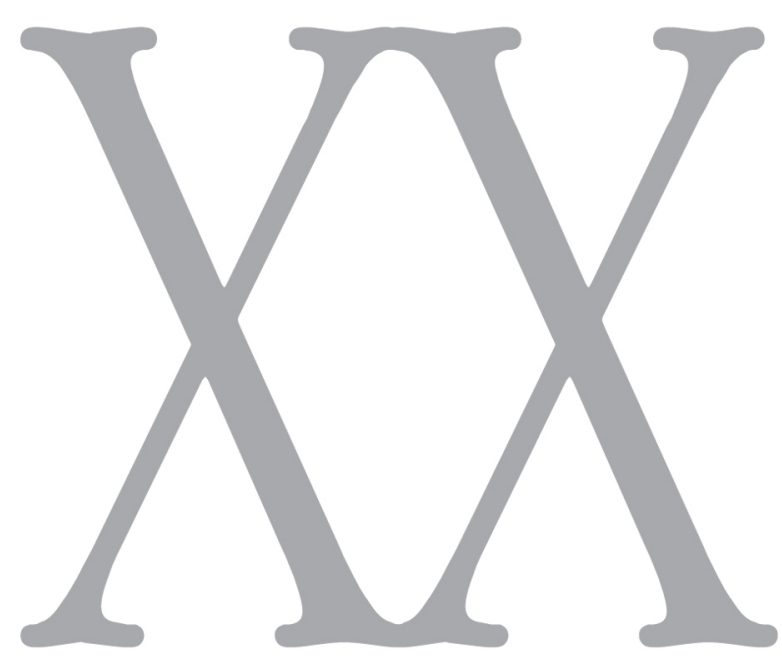

número 15 • 2015

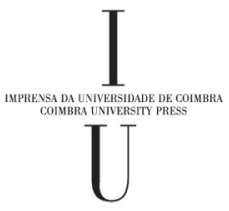




\title{
I connect, therefore I am!
}

Places, locales, locations and informational territorialization

\author{
André Lemos \\ Rodrigo Firmino
}

André Lemos, Professor Faculdade de Comunicação da Universidade Federal da Bahia, Brasil.Email: alemos@ufba.br.

Rodrigo Firmino, Professor do Programa de Pós-Graduação tão Urbana e do Curso de Arquitetura e Urbanismo da Pontifícia Universidade Católica do Paraná, Brasil. Email: rodrigo.firmino@pucpr.br

http://dx.doi.org/10.14195/1647-8622_15_1 
CONECTO-ME, LOGO ESTOU! LUGARES, LOCAIS, LOCALIDADES E TERRITORIALIZAÇÃO INFORMACIONAL

O que nos conecta a determinados locais? O que determina a posse ou apropriação de certas localidades? Qual o nosso lugar? Quais as fronteiras informacionais dos lugares e territórios na cidade contemporânea? Neste ensaio, discutimos as particularidades epistemológicas desses conceitos e procuramos diferenciá-los para tornar clara e possível a caracterizaçáo de processos de espacialização informacionais a partir de conexôes tangíveis e intangíveis entre nossos corpos, mentes e nossa presença infocomunicacional no espaço. Buscamos construir um entendimento de como é possível refletir sobre as diferentes formas de espacialidade (territorializaçóes, lugarizaçôes, locais, localizaçôes, etc.) e o recente avanço da experiência humana com as tecnologias de informação e comunicação (TIC), em especial aquelas mais diretamente relacionadas com, ou dependentes de, funçôes de geolocalização e controle. Por fim, sugerimos a politização de lugares e tecnologias para a compreensáo de processos de reconfiguraçáo de locais e de suas condições de lugarização.

Palavras-chave: Lugar, Local, Territorialização informacional, Controle
I CONNECT, THEREFORE I AM! PLACES, LOCALES, LOCATIONS AND INFORMATIONAL TERRITORIALIZATION

What connects us to certain locations? What determines the possession or ownership of certain locales? What is our place in cities? What are the informational boundaries of places and territories in contemporary cities? In this essay, we discuss the epistemological particularities of these concepts and try to differentiate them in order to clarify the processes of informational spatialization through tangible and intangible connections between our bodies, our minds, and our info-communicational presence in space. We seek to build an understanding of how to think through the different forms of spatiality (territorialization, placemaking, locales, locations, etc.), and the recent developments in the human experience with information and communication technologies, especially those most directly related to, or dependent on, geolocational and control functions. Finally, we highlight the importance of politicizing places and technologies to improve understanding of the processes involved in the turning of locales into places.

Keywords: Place, Locale, Informational territorialization, Control
JE ME CONNECTE, DONC JE SUIS! PLACES, LIEUX, ENDROITS ET LA TERRITORIALISATION INFORMATIONNELLE

Qu'est-ce qui nous connecte à certains lieux? Qu'est-ce qui détermine la possession ou l'appropriation de certains endroits? Quelle est notre place? Quelles sont les frontières informationnelles des lieux et des territoires dans la ville contemporaine? Dans cet essai, nous discutons les particularités épistémologiques de ces concepts et nous cherchons à les différencier pour rendre claire et possible la caractérisation des processus de spatialisation informationnels à partir de connections tangibles et intangibles entre nos corps, esprits et notre présence info communicationnelle dans l'espace. Nous cherchons à construire un entendement de la façon dont nous pouvons réfléchir sur les différentes formes de la spatialité (territorialisations, localisations, lieux, endroits, etc.) et la récente avancée de l'expérience humaine avec les Technologies de l'Information et de la Communication (TIC), notamment, celles qui sont en rapport plus direct avec, ou dépendantes de, fonctions de géo localisation et de contrôle. Finalement, nous suggérons la politisation des lieux et des Technologies pour la compréhension des processus de reconfiguration des endroits et de leurs conditions de localisation.

Mots-clefs: Lieu, Local, Territorialisation informationnelle, Contrôle. 


\section{Introduction}

\section{I had a shelter, not a home. (Mia Couto)}

The stream of literature that considers place is wide and epistemologically rich (see, e.g., SACK, 1993; FLEMING, 2007; TUAN, 1980; FRIEDMANN, 2007; MASSEY, 2005; SANTOS, 1992; DUARTE, 2002; LEMOS, 2010b, to name a few). Placemaking processes have been the subject of studies in geography, history, architecture, urban studies, sociology, psychology, among numerous other knowledge areas to which the man/space relationship has some importance. In Key Thinkers on Space and Place, Phil Hubbard and Rob Kitchin present a list of 65 thinkers $^{1}$ from different periods in history that have acted as key references in studies and discussions about space and place, and the role of these concepts in the social, cultural, political and economic aspects of contemporary life.

The relationship between man and space is, indeed, important to numerous fields of science. The 2014 Nobel Prize in Physiology or Medicine was shared among the neuroscientists John O'Keefe, May-Britt Moser, and Edvard I. Moser for their discoveries on how a sense of location and a sense of connection to certain locales are generated in the brain. In 1971, O'Keefe discovered a relationship between the activation of certain nerve cells in the hippocampus and the location in space, concluding that "place cells" create a map of where our bodies are (O'KEEFE, 1979). In 2005, based on O'Keefe's findings, May-Britt Moser and Edvard I. Moser found that another group of brain cells are responsible for forming "grid cells," which function as a system of coordinates (HAFTING et al., 2005). Thus, the set formed by this cellular grid, the place cells, the direction of the head, and the perception of the limits of where we physically are, forms a highly efficient biological global positioning system.

In the present study, however, we move away from this scientific accuracy to characterize what our relationship might be with the spatialization processes of our bodies and minds. We seek to understand how it is possible to reflect on the different forms of spatiality (territorialization, placemaking, locales, locations, etc.) and the recent advance of human experience with information and communication technologies (ICTs), especially those that are directly related to, or dependent on, geolocational and control functions.

The aim of this study is to discuss some conceptual frameworks bound to the geographic space and relate them to what we call "informational territorialization" $\left(\right.$ LEMOS, 2007) ${ }^{2}$ - supported by the increasingly complex relationships between man, space, and ICTs. This need arises from the convergence between the areas of communication and urban studies. Here, we discuss the socio-technical placemaking

\footnotetext{
${ }^{1}$ This can be seen as a modest list, considering the fact that it does not include Latin American and Iberian thinkers such as Milton Santos and Horacio Capel Sáez (both winners of the Vautrin Lud Prize in Geography, in 1994 and 2008, respectively).

${ }^{2}$ The concept of informational territory was first proposed by Lemos (2007) to describe new forms of informational control in the urban space. We expanded the discussion in this article. On the process of territorialization, see also Firmino (2011).
} 
and territorialization processes as the material bases of our own existence, and the notions of place, locale, location, and territorialization amid the expansion of ICTs.

The remainder of this essay is divided into three main parts. The first is dedicated to clarifying the conceptual boundaries between location, locale, and place. In the second part, we focus on generating a discussion of how these geographical dimensions behave in the face of communication, information and the various possibilities of territorialization. Finally, we conclude by summarizing the key points of this debate and pointing to the need to politicize places and technologies.

\section{The Locale of the place}

Place can be said to be a locale filled with individual or collective meaning (related to identity, history, politics, culture, etc.). It could be "my place" (individual), or the manifested place of certain collectives (protests, parties, etc.), which momentarily appropriate a locale to make it their place. The locale is only a portion of the space, without entailing an a priori definition of dimensions. When we appropriate this portion of the space, this locale, by means of affinity, ethnic or cultural ties, political associations, or personal affections, we attach a sense of belonging to this locale and make it a place. Therefore, not every locale is a place.

The place is not an ontological property of the locale, but an individual and collective construction-just as color is not an ontological property of matter. We assign a color from our cognitive apparatus, just as we appropriate a portion of the space by means of our cultural associations, thereby turning it into a place. A place is something that is assigned to the locale; it is a human construction, a certain value (CRESSWELL, 2004; PRED, 1984).

In the present study, we focus on the changes that have occurred in how places are understood and experienced based on the evolving relationship with ICTs. Since place is a locale that is appropriated by some and not others, and sometimes from appropriations delimited in time, one must be aware of the territorialization dynamics. ${ }^{3}$ In order to understand these dynamics, we define territory as control mechanisms acting in a certain locale (DELANEY, 2005; GOTTMAN, 1973; RAFFESTIN, 1988; SACK, 1986). The territorialization process gives sense to locales, regarding them as territories (by some sort of demarcation and control) and places (by some affective appropriation). Control and affection, determination and belonging, thus define important properties in the differentiation of possible appropriations of a locale. These properties are part of the territorialization processes, and qualify locales as places and/ or territories (related to the individual and/or collective subjects of these actions).

Thus, the control mechanisms are those that differentiate place from territory. ${ }^{4}$ Normally, a territory is bound to laws, documents, institutions, and rules of coexistence

\footnotetext{
${ }^{3}$ It should be noted that "territorialization" here refers to a process that also involves "deterritorialization" and "reterritorialization."

${ }^{4}$ Today, there is no place on planet Earth that does not constitute a territory. Ontologically, we can state that a territory is a locale, but a locale is not necessarily a territory (with the exception of all locales
} 
for maintaining its limits, power, and domination. These control instruments can be bound to the locale so that it becomes a place, but only if this is a condition for the common coexistence, belonging, sharing values (TUAN, 1980). The nation-state represents institutionalization of the territory and the search for a perfect match between place and territory. A nation-state's territory is defined by borders, customs, and sociocultural elements (wherein some are always at the expense of others) in hopes that they express, for the population understood within this territorial design, a common sense of belonging to the geographical and topological base enclosed by its borders.

Territorialization processes are essential to the creation of a place, since territories arise a result of these processes (HAESBAERT, 2004). The locale is a portion of the space formed due to the influence of various networks: technical, social, imaginary, communicational, geopolitical, etc. This event-that is, this interrelation of networks that combine, even momentarily, and are materialized or mediated by specific factors-is what we mean by "space." Places are portions of space, but space is only created in the dynamics between locales (whether they are places or not). This means that there is no order of size between space and locales - where one is larger than the other-but a level of interdependence. Space is a network of events that are materialized (LEMOS, 2013) or mediated by solid elements, but it has a dynamic existence, being deformed by the tensions between the different locales (and other objects) that constitute it.

We have already made it clear that there is an important conceptual distinction to be made between space, territory, and place, which are sometimes used interchangeably-and thus lose the conceptual strength that each term has for the understanding of related, but distinct, phenomena. In addition, place is sometimes used as a synonym of locale or location.

John Agnew (1987 cited in CRESSWELL, 2004) distinguishes location, locale, and sense of place. Location refers to a geographical position, the "where" marked by latitude, longitude, and altitude. Locale covers the point in space at which this location is situated, but it already has an attributed meaning-in the case of urban areas, this would mean the city, the neighborhood, the square, etc. The place depends on a sense of identity or belonging assigned to a locale, or a portion of it. In order to be a place, a locale needs to have a sense of meaning. The place is a social dimension assigned to the locale, which in turn has a location.

In this article, we use the notions of locality, locale, and place. We have chosen to use "locality" rather than "location" because the former allows us to work with the sense of something built on the space, while the latter would only indicate georeferenced coordinates. For example, an object has a location in space, but it is not a locality (though it is likely to be inside one). Thus, we use locality because an object has a location, a locale has a location, a locality has a location, and therefore a place has a location. Locality refers to a construction in space with which a meaning (place) may or may not be associated.

on the planet). However, the act of naming is a form of appropriation and control, albeit a very subtle one. Naming (nomos) is always an exercise of power over something. In this sense, every locale named by humans could be understood as a territory. However, in terms of our focus here, which is the human space on planet Earth, we can certainly say that a locale is a territory. 
For clarity and synthesis purposes, from the above discussion, we propose the following concepts and their definitions:

Locality: network formed in the relationship between locales (force/tension in and between locales). This can refer to all localities known to mankind and that are part of our domain, the known universe (the Moon, Mars, or the Andromeda Galaxy), the globe (dynamics of all localities), or a more limited dimension (the neighborhood, the city, the state).

Locale: formed by territorializing and deterritorializing processes that have a location (a street address, a precise indication of latitude and longitude- such as a specific bakery, supermarket, lake, square, obelisk, etc.). The locale is a portion of the space identified by a set of value elements that puts them in a position relative to other locales according to some reference system (mathematical, use and function, georeferential, etc.).

Place: a locale filled with meaning (related to emotion, identity, history, politics, or economy), which can be individual ("my place") or collective (the places where collectives are protested or celebrated). The place is thus a portion of the space that is filled with socio-cultural values, and thus gives these values meaning and differentiates them by means of an affective relation to individuals or groups.

Territorialization: control processes ${ }^{5}$ that constitute any place on planet Earth. The associations or social appropriations by actors and specific actions form the assignment of values and power relations.

The above definitions of these qualities of the space form the backdrop of this article. Our focus is specifically on understanding the constitution of places-specifically urban places-from the understanding of how ICTs (through informational territorialization processes) influence the way these (urban) places are constantly transformed.

\section{Information, Communication and Territorialization}

if space is the matrix concept of all others (that is, territories and places are portions of the space appropriated by assigning meaning), in each portion of the space, in each locale, there is a confluence of several processes that constitute it. For example, a town square: the municipal laws, the habits of users, the gangs that traffic drugs at night, lighting control, surveillance cameras, Wi-Fi, and $3 \mathrm{G}$ networks, are all components of the square beyond the material aspects (such as street furniture or vegetation). These components-some of which are fixed but invisible, while others are visible but are not coded as components of a square, transform their uses. Therefore, the locales are constantly reconstituted by means of the processes of appropriation and use through new territorializing processes.

\footnotetext{
${ }^{5}$ We speak of control, but refer to a process that can also consist of a loss of control (deterritorialization) or new forms of control (reterritorialization).
} 
The availability of communication and information networks, whether free or paid, transforms the use of the square, attracting people, as well as enabling the inauguration of new urban equipment, such as a park for children or an exercise area for adults. The repercussions of urban infrastructure are well known. They are explicit, visible. However, the new practices arising from informational territorialization processes are not yet as well understood. This gap is precisely the motivation behind this article: we highlight how ICTs, as elements introduced within a locale, bring new territorializing processes, and resize it, with or without creating new forms of ties that may later establish it as a place.

ICTs can change habits and create forms of belonging through the provision of access to communication and information networks (Wi-Fi). This informational territorialization is another important factor of the dynamics (tension and accommodation) in and between locales. We propose a reflection on some territorializing processes in locales that are already established (e.g. a cafe, square, shopping mall, library, university, hotel, airport), or are to be established. These processes will negotiate with other territorializing processes that establish these locales.

In today's digital culture, informational territorialization is an element used in the placemaking process of locales, because they establish attraction and viscosity (in, for example, finding a zone for $3 \mathrm{G}$ or Wi-Fi, using Bluetooth or near field communication, accessing images taken by surveillance cameras, etc.). However, contrarily, locales will also use the strategy of denying this informational territorialization in order to differentiate and establish their placemaking conditions (for example, a cafe that does not offer Wi-Fi in order to position itself as a place for customers to drink coffee and talk). Even in this case, the main argument remains: locales are established through territorial processes and ICTs add yet another one of these processes: informational territorialization.

Locales are always made up of control relations (territorialization) and escape lines (appropriation, deviation, or deterritorialization). Laws, customs, history, uses, etc., establish and shape locales, create places or territories, and establish a network we may call a locality. The search for connection takes place from specific instances of access to digital networks, and becomes part of locales. This access is a form of informational control of the locale, and thus becomes a part of it.

\section{Informational territorialization in wireless networks}

In order to facilitate understanding of these new informational territorialization processes, we can illustrate them using some examples. ${ }^{6}$

An article in the Brazilian newspaper $O$ Globo from April 23, 2013 drew attention to the importance of Wi-Fi for the purchase of a property. ${ }^{7} \mathrm{New}$ buyers disclosed

\footnotetext{
${ }^{6}$ The examples in this section were taken from André Lemos, "Mídias Locativas, Espaço e Território Informacional" (forthcoming).

7 "Inside the house but off the cover area" ("Dentro de casa. Mas fora da área de cobertura"). http:// oglobo.globo.com/imoveis/dentro-de-casa-mas-fora-da-area-de-cobertura-8175897
} 
to the journalist that they did not want to face the inconvenience of buying an apartment and later finding out that a mobile signal, or $3 \mathrm{G}$ and $4 \mathrm{G}$ networks, were not available.

A 2013 television ad showed a couple entering an establishment, such as a gym or pizza restaurant, and asking obvious questions (such as: How much does a $3 \mathrm{~kg}$ dumbbell weigh? Is the pizza round? Does it have cheese on it?). In fact, the couple entered these places only in order to use the Wi-Fi connection. At the end of the ad, a voice-over stated the couple could access a $3 \mathrm{G}$ connection and no longer depend on the Wi-Fi of other establishments-thus no longer depending on the informational territorialization linked to other locales.

These examples show that in locales such as colleges, homes, or squares, it is common to see people looking for places where the cellular connection or the $3 \mathrm{G}$ signal for Internet access is stronger, or where there is a Wi-Fi hotspot for internet connection on tablets, mobile phones, or laptops. It is common to see people complaining, upon arriving at a cafe, restaurant, classroom, or auditorium, if there is no available wireless Internet. Today, locales are redefined by network connections that enable communication exchanges to take place in many different ways. The uses of locales and objects are becoming increasingly linked to such info-communicational access. Being in the urban space involves being constantly connected through a multitude of networks and objects; that is, being subject to informational territorialization (LEMOS, 2007).

An easy exercise here is for the reader to turn on a mobile device (such as a smartphone, tablet, or laptop) and seek a Wi-Fi connection. The list that appears on the device clearly shows the locations that are marked by informational territorializations and forms of access (open or closed, where the latter is usually denoted by a padlock). Another way is to check for 4G, 3G, HSPA, or Edge connections at the top of the smartphone's screen. The signal strength (number of bars) or type (Edge, 3G, 4G) shows the type of informational territory. The user must know how to access this territory (for instance, through pre-paid, post-paid or open access accounts). Yet another approach here would be to test the existence of this form of territorialization as defined by the amount of applications that use the user's geolocation to provide the service or perform the action for which it was developed (for example, an application such as Waze will only work if it is able to use the geolocation data, while other applications require location access only to add an information layer to their purpose, which may be independent of georeferenced information), and the ways in which these applications are related to each other, to the device, and to the user.

Another example can be found at the food court of the Barra Shopping mall in Salvador, Brazil. Many people frequent this food court often, especially at lunchtimes. The administration has made the area a Wi-Fi zone (where access is controlled, but free). However, to prevent people from using the food court more for Internet access than for eating (the locale's originally defined functional purpose), the mall administration decided to interrupt the Wi-Fi signal between the hours of 12 and 2 pm each day. This demonstrates how new territorialization and deterritorialization dynamics change the sense of locales and, consequently, the sense of place. 


\begin{tabular}{|c|c|}
\hline $\begin{array}{lc}\cdots \cdots \cdots \bullet \text { vivo } 3 \mathrm{G} & 17: 17 \\
<\text { Ajustes } & \text { Wi-Fi }\end{array}$ & $90 \%$ \\
\hline GVT-RTA & 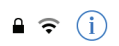 \\
\hline hamburguer & $\pm \approx i$ \\
\hline HP-Print-A7-Deskje... & $a \approx i$ \\
\hline INTELBRAS & $a=(i$ \\
\hline J.J & $a=(i$ \\
\hline kay & $0=(i$ \\
\hline Mgelband & $a=(i$ \\
\hline QT 26 & $a=i$ \\
\hline quillsjeans & 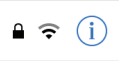 \\
\hline schooner & $a=(i$ \\
\hline UrbanKulture & $\pm \approx(1)$ \\
\hline
\end{tabular}

Figure 1: Traces of informational territories

Source: Authors

Another means of understanding this is by mapping Wi-Fi zones. Mapping Wi-Fi hotspots (such as Wi-Fi Salvador ${ }^{8}$ ) shows the stage of development of this informational territorialization in a city, and the locales at which there is informational territorialization (this can also be demonstrated via the use of applications, which, in addition to mapping Wi-Fi hotspots, provide access passwords to closed networks, such as the application Mandic Magic). When looking at the city map, we can quickly see the relationship between these territories and the geopolitics of the city's neighborhoods. A map of cell phone antennas and $3 \mathrm{G}$ and $4 \mathrm{G}$ technologies would also provide an idea of this informational territorialization. All cities are turning into large informational territorialization areas, since all locales (and of course their practices) are changing concomitantly. The informational territorialization will, hypothetically, tend to coincide with the available area across all parts of the planet.

Informational territorializations can also be identified through signs posted in public spaces or commercial establishments. In malls, cafes, restaurants or public squares, it is common to see the universally adopted pictogram for Wi-Fi connection areas, which informs visitors whether there are Internet access zones in the area, and whether they require access passwords. Seeing people sitting in an establishment, grouped together with their laptops in a specific area of the locale, is also a means by which to identify that the connection is stronger in that area. We can thus establish the existence of informational territories.

\footnotetext{
${ }^{8}$ These maps can be viewed at http://wifisalvador.com, or using Android or iOS applications.
} 
On the island of Boipeba, in the state of Bahia, Brazil, the formation of queues at some specific outdoor locales highlights the informational territorialization and the new senses of places being formed. People gather in order to gain access to mobile phones and $3 \mathrm{G}$ networks. The coordinates given by natives so that tourists can access a given operator assume a comic narrative: "Go to the square, take 10 steps, turn left, put your right foot up on the stone, and you'll have a full-bar connection”. The same search for access to informational territorialization applies to the case illustrated in Figure 2, in which African migrants in the Djibouti port raise their cell phones at night in order to connect to a cheaper signal in neighboring Somalia. ${ }^{9}$

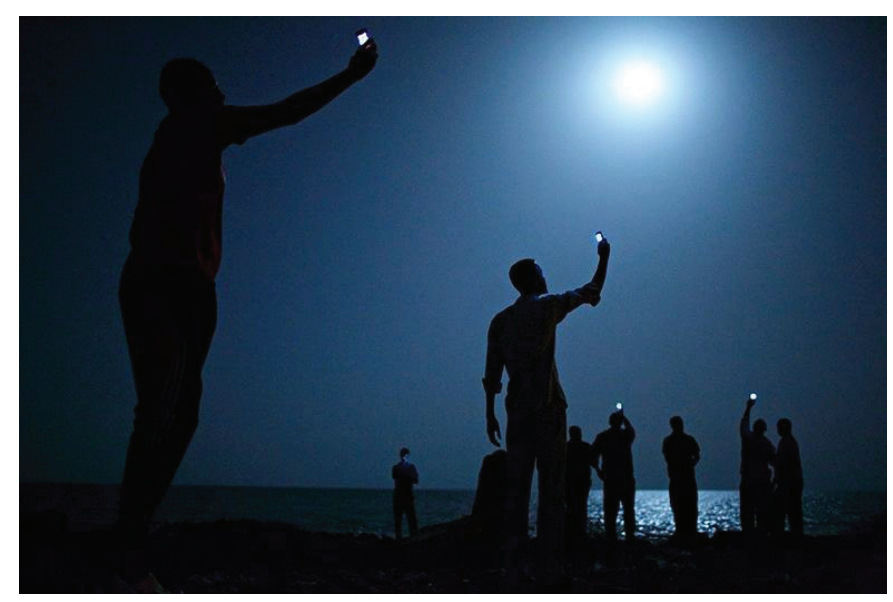

Figure 2: reaching out for informational territories, Djibouti and Somalia. Photograph by John Stanmeyer/VII Agency

These examples show how locales are transformed via informational territorialization. In the last example, this transformation is shown in an even more radical and interesting way, because we are witnessing an attempt to contact an economically defined informational territory (different cellular companies operating in the border area in question) in a locale marked by a traditional political territorial tension (specifically, the border area between two countries).

In the arts, there are several examples of informational territorialization processes, especially Wi-Fi access zones. The Swedish study "Immaterials: Light painting Wi-Fi," ${ }^{10}$ by Timo Arnall, Jørn Knutsen and Einar Sneve Martinussen, shows images of the Wi-Fi connection signals available in locales as electromagnetic walls. The final study allows us to specifically see the informational territorialization, its weaknesses, and its reliefs (strengths and weaknesses in a given location). As the authors state:

\footnotetext{
${ }^{9}$ See http://www.theguardian.com/world/picture/2014/feb/15/eyewitness-djibouti-world-press-photo-stanmeyer?CMP=twt_ipd

${ }^{10}$ See http://yourban.no/2011/02/22/immaterials-light-painting-wifi/
} 
The city is filled with an invisible landscape of networks that is becoming an interwoven part of daily life. Wi-Fi networks and increasingly sophisticated mobile phones are starting to influence how urban environments are experienced and understood.

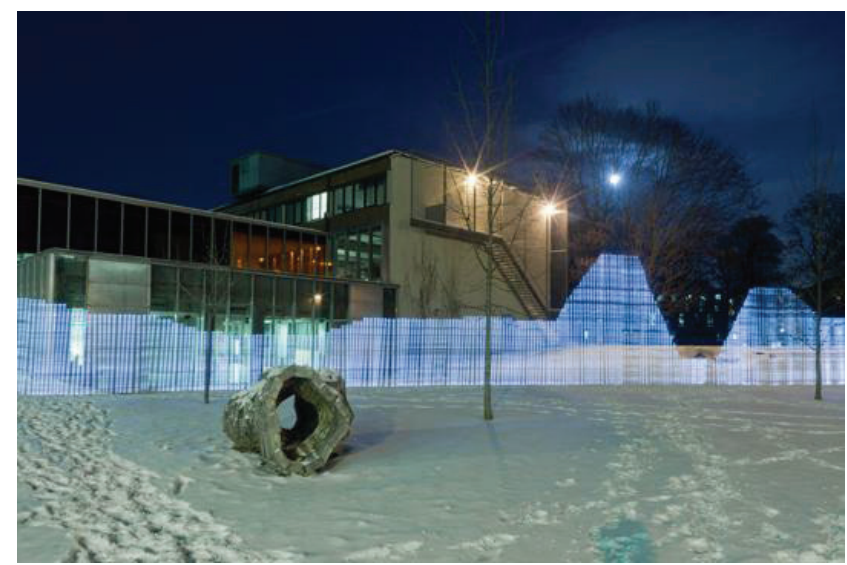

Figure 3: Immaterials

Source: http://yourban.no/2011/02/22/immaterials-light-painting-wifi/

Another way to view the locales and their relationship with informational territorialization is with reference to the work of Clara Boj and Diego Diaz, known as "Observatorio," wherein users look through a telescope to view open and closed Wi-Fi zones in several cities in Spain. ${ }^{11}$

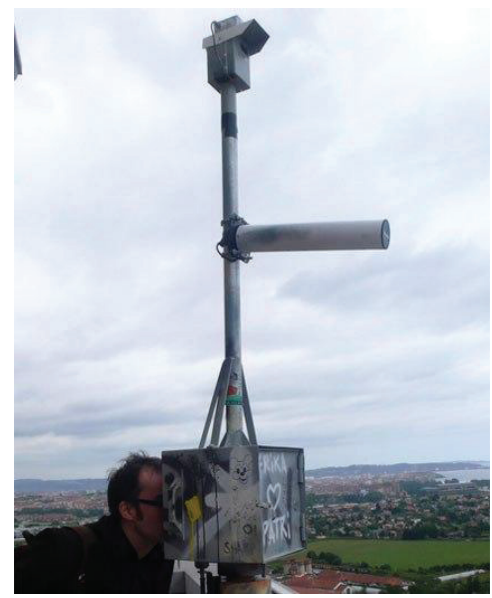

Figure 4: Observatorio

Source: http://www.lalalab.org/observatorio/

${ }^{11}$ See http://hackaday.com/2008/06/10/wifi-telescope/ 
On the other hand, the work "Disconnected," by artist Susan Härtig, provides an excellent example of perception and visualization by blocking access to informational territories. This Canadian artist aimed to demonstrate how connections via wireless network zones (radio waves) of mobile phones, radio-frequency identification, Wi-Fi, or Bluetooth create access zones and informational flows that increasingly expand. In contrast, the study then attempted to block the radio spectrum, and thus disconnect people, by blocking access to informational territories. Users stood within a tent created by Härtig, which isolated them and annihilated the informational territory by creating another territory (another form of control) that prevented access to the electromagnetic cloud. According to the author:

The human being is embedded into an invisible telematic network, and thus can itself link at any time with other humans over these available networks. By this data dispersion he/she can be increasingly topographically located? How can one escape the interference in a private space in spite of increasing mobility or create a private retreat place in its environment? ${ }^{12}$

\section{Informational territorialization in surveillance systems}

As we have seen above, the relationship between locale and place can occur in various forms, and placemaking necessarily involves appropriation processes. This may occur at different scales. On the neighborhood scale, we have observed a phenomenon in which the placemaking process goes beyond the specific features of affection and simple wellbeing created by some artifice of urban design and architecture. In some cases, paths lined with trees, proper paving, well-built sidewalks, green areas, areas that facilitate movement, and even a good distribution of squares and parks, are not enough.

Safety (or a sense of lack thereof) can be configured as one of these missing elements. Safety mechanisms can help diminish certain local disturbances in order to reaffirm feelings of belonging, and thus create a basis for the emergence of a proper sense of place. We must recognize that disturbances and tensions also build the place, and any territorial process is unable to completely eliminate all disturbances and conflicts. In contemporary cities, there seems to be a trend determined by territorial control and power relations to increase local security (FIRMINO ET AL., 2013). This relates to electronic surveillance as a form of informational territorial expansion.

Here, we can analyze a neighborhood in Curitiba, Brazil, in which this territorialization can be observed. The upper-middle-class neighborhood (locality) in the city of Curitiba is well served by trade and vicinal services, and good urban and landscape infrastructure, and is mainly residential. The government provides it with all the physical characteristics necessary to enhance the desired sense of urbanity and belonging to a "place." However, the neighborhood is also governed by a sense of violence and

12 For details, see post by Networked Performance: http://transition.turbulence.org/blog/2007/11/02/ disconnected-by-susan-hartig/\#more-5788 
lack of security, and thus implements strategies by which control use, access, and circulation in the various locales that establish it, notably via the use of security and alert systems (alarms, cameras, electric fences, community alarms, etc.), which are often monitored by private security companies. This informational territorialization is used as a facilitator (or condition) so that residents can feel safe.

Traditional control strategies are also implemented, such as high walls, barbed wire and electric fences, guard dogs, etc. As we can see, territorialization through actions to increase the sense of safety has long been under way, but is now subject to informational contours: a computerized security system that controls access to the locality (the neighborhood) has been added. It is important to emphasize that we are not dealing solely with a private place of residence here, but with portions of the public space.

In most cases, residents of some parts of the neighborhood have collaborated to install monitored security systems (involving, in most cases, surveillance cameras) on the private limits of their properties, yet with the aim of controlling the public space (cameras are installed on the lampposts outside homes, but are aimed at the public street or a nearby square). In most cases, a private security company is responsible for monitoring the system and addressing situations that are considered abnormal. Regardless of the use of these companies, however, these systems are connected to a modem capable of transmitting the camera images to the residents' mobile devices. Figures 5 and 6 illustrate this concept within territorialized locales.

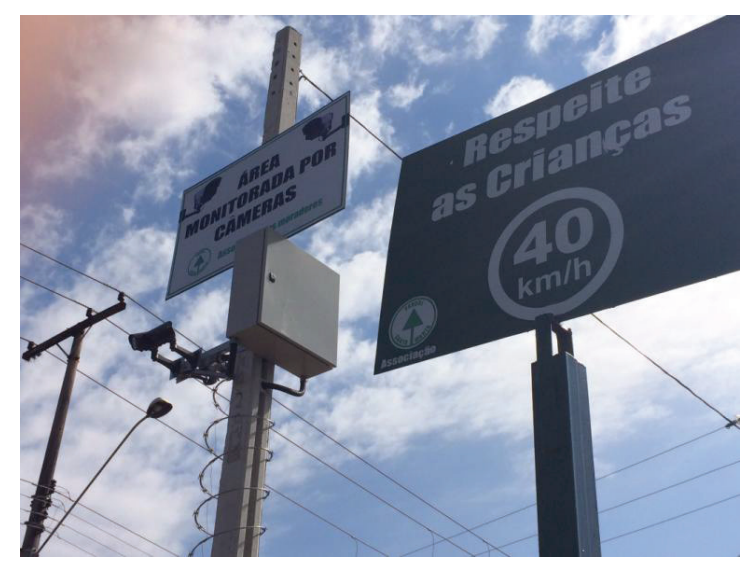

Figure 5: Cameras and children, demarcated territory. Sign on the left: "area monitored by cameras". Sign on the right: "respect our children, $40 \mathrm{Km} / \mathrm{h}$ limit".

Source: Authors. 


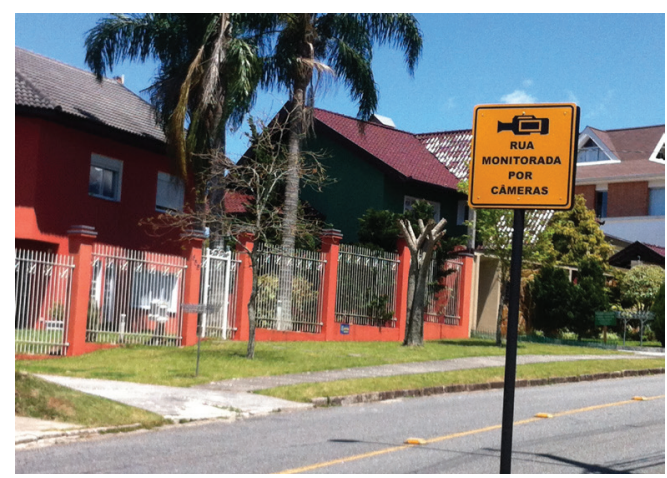

Figure 6: "Caution, area under surveillance!" Source: Authors

One specific situation illustrates the use of these systems through informational territorialization. A group of five or six residents, who are neighbors, installed four cameras to monitor each opposite side of the street (with two on each side). The four cameras are connected to the hub of a private security company, and remotely to the residents' mobile devices.

Due to the dispersion, distribution, and control features inherent in this scenario, it can be called what Firmino and Duarte (2014) referred to as "splintering smart surveillance," 13 which is capable of encoding a new territorial layer in the city. Thus, the street in front of the residence is controlled through informational territorialization in order to facilitate the placemaking process in the neighborhood.

Obviously-and this only reinforces our hypothesis here-a double purpose is connected to this territorialization process through surveillance and security mechanisms. That is, while it can create situations in which the sense of comfort and security (for example, for residents) is determined by the mere presence of the devices, this existence and visibility can be a source of disruption and instability for the people who have other relations of place and belonging (such as frequent passersby or occasional visitors) within these same locations.

Within this double relation of placemaking and place-unmaking, it is interesting to note that Mirelo Rosello (2008 cited in LEMOS, 2010) presented a dimension of not only space, but also time in the use of surveillance cameras. Rosello (2008) explored the emergence of what she called the "unsafe subject" (sujet insécure). To Rosello, the issue of insecurity is key to understanding contemporaneity. Surveillance cameras, for instance, create a culture of insecurity. The interesting thing about Rosello's argument is that we must recognize the influences of the very materiality of the devices. Regarding CCTV,

${ }^{13}$ This is an allusion to the term "splintering urbanism" created by Stephen Graham and Simon Marvin, which refers to a broad and complex process of fragmentation and dispersion of various aspects of urban life, from the also fragmented construction and distribution of contemporary urban infrastructures (GRAHAM and MARVIN, 2001). 
Rosello shows that they [the cameras] present data where users demonstrate that the simple installation of a camera creates fear, vulnerability and insecurity, regardless of the resolution of the problem of crime. The camera stimulates, on the one hand, a positive reaction, producing the idea that there is a security problem in place and this will solve it. On the other hand, it creates a sense of fear and insecurity over time, past, present and future: regarding the present, because the simple insertion of the device brings the idea that "something is happening here"; regarding the past, because "something could have happened"; and regarding the future, because "something might happen". The materiality of the device alters the relationship with the space/place, producing a sense of insecurity. And it matters little whether this uncertainty will be resolved or not. Fear takes place in the present ("the camera is there to protect us from something"), in updating the past ("we should have been afraid before"), and in the future ("we'll have problems, or they'll be stopped”). (LEMOS, 2010a, p. 67)

In this context, we can extend this analysis to other forms of surveillance that use the power of new informational territorializations, largely expanding the action of surveillance cameras to mobile systems, which are able to locate using sensors, wireless networks, and mobile devices. The issue of electronic surveillance refers directly to a tension between informational territorialization and the constitution of locales and places.

\section{Viscosity and textures}

With informational territorialization, locales change. We can even create a Wi-Fi network on the Moon. ${ }^{14}$ We need to recognize this new territorializing process among many others that establish locales and places. There are as many means of territorializing as there are of controlling, and these change with every development period (technological and cultural) of humanity. We consider informational territorialization processes important here as they still seem to be undervalued by communication and urban studies. Technological determinism and essentialist views on what constitutes a place, help obscure these processes.

In contemporary culture, locales are going through informational territorialization processes, and today it is even difficult to find an urban area in which network access is non-existent. We saw earlier that even on the secluded island of Boipeba, in Bahia (Brazil), these processes are in place-but there, as in Djibouti, informational territorialization still marks the difference between connected and unconnected locales.

Here, we have attractiveness (the calling), viscosity (the adhesion) and texture (practices that configure, or will configure, locales) as important actions of informational territorialization. Attractiveness or viscosity (SHIRVANEE, 2006) refers to the dynamics of localities regarding their attractions, customs, and social practices. With

\footnotetext{
${ }^{14}$ NASA has had plans to implement the Internet on the moon since 2013, when the organization managed to fire the world's fastest Internet connection toward the Lunar Atmosphere and Dust Environment Explorer (http://www.dailydot.com/technology/fastest- internet-ever-laser-beam-moon/), transmitting data between Earth and the moon at a rate of 19.44 megabits per second. The researchers behind the experiment unveiled the full details at the CLEO: 2014 conference (http://www.cleoconference.org/home/).
} 
this in mind, we will now turn the discussion to locative media and the processes that create social viscosity. Viscosities created by informational territorializations are at stake here (LEMOS, 2007, 2008). These new processes that allow access to digital networks and services have been shown to cause people to stay longer, while they also seem to have some difficulty leaving squares, cafes, and other hotspots. Viscosity is, thus, a very interesting concept to show how localities are gradually turning into places through various contemporary informational territorializations. As stated by Shirvanee (2006),

Emergent collective activity in social groups creates a condition [called] a "social viscosity", where high connectivity and a velocity of flow create a resistance to bring about a trend of movement. Here, viscosity is defined as a dynamic force of flow between social groups that can form depending on levels of communication, ranging from the private to one that is very public.

Texture (JANSSON, 2006) is precisely what causes viscosity; that is, special spatial configurations in the localities, which give it distinct characteristics. We may hypothesize that viscosity and texture help constitute places, thereby transforming localities into places. In contemporary information society, forms of informational territorialization act accordingly. Jansson, corroborating our view, pointed out that texture helps us move away from the sense of space as a container; to Jansson, "textures contain aspects of both spatial structure and spatial/communicative practices" (2006, p.91). Moreover: "Communication thus produces space, by way of texture, in a very material sense" (2006, p.99).

The concepts of viscosity and texture applied to space and communication studies offer a different view of the ideas of "alocality" (RELPH, 1976) or "non-places" (AUGÉ, 1995). When studying in detail the textures of space, we found specific communicative arrangements that differ in space and time. Texture, therefore, connects a spatial and communicative dimension.

\section{Conclusions: politicizing places and technology}

In this article, we focused on forms of informational territorialization and how they define places, locales, territories, and localities. The aim of this discussion was to highlight the formation of placemaking processes (FIRMINO and DUARTE, 2012) via the relationship between ICTs and urban space. We showed how locales are reconfigured, with or without the creation of forms of belonging, with practices that involve cell phones, Wi-Fi networks, and surveillance cameras.

The invisibility of these processes (including wireless networks, distributed electronic surveillance, use of mobile devices) often prevents us from seeing true "spatializing" facets (factors that create tension between locales, territories, localities and places) of the new computerized technological systems. The goal of this paper was to draw attention to this process. Due to its role in defining contemporary and local places (and the actions arising from these spatializations), network access through informational territories should be seen as a civic right and a duty of the State. 
With regards to the use of public spaces, access to information and telematic networks, and the issue of electronic surveillance, we are dealing with a highly sensitive issue of contemporary culture that deserves to be politicized. Failing to take these informational territorialization processes into account would mean excluding key elements of the establishment of locales and places from the political debate. These processes foster forms of sociability and can be important elements in the production of meaning of locales that produce places.

Urban managers, social scientists and communication experts should be aware of these processes, as the ubiquitous networks and ICTs put informational territorialization as one of the major reconfiguration processes of locales and their placemaking conditions (virtual process of transforming a locale into a place by means of belonging, identity, and personal or collective feeling). We have seen how ICTs create viscosity and texture processes; understanding these new processes through the relationship with info-communicative socio-technical systems can help to broaden the debate on urban and communication studies, as well as help to provide a deeper understanding of the reality of contemporary cities.

\section{Acknowledgments}

We would like to thank Fábio Duarte for the valuable and essential comments provided during the initial construction of this essay. We also express our gratitude to $\mathrm{CNPq}$ for the funding that directly and indirectly supported the research projects that enabled the reflections included in this text.

\section{References}

AUGÉ, M. - Não Lugares: Introdução a uma antropologia da sobremodernidade. Bertrand Editora, 1994.

CRESSWELL, T. - Place: A short Introduction.Malden. USA, Oxford, GB, Victoria, Australia: Blackwell Publishing, 2004.

DELANEY, D. - Territory, a short introduction. MA, USA: Backwell Publishing, 2005.

DUARTE, F. - Crise das matrizes espaciais. São Paulo: Perspectiva, 2002.

FALKHEIMER, J.; JANSSON, A (Eds.) - Geographies of Communication: The Spatial Turn in Media Studies. Nordicom: Goteborg, 2006.

FLEMING, R. L. - The Art of Placemaking: Interpreting Community Through Public Art and Urban Design. London: Merrell Publishers, 2007.

FIRMINO, R. - “Território e materialidade: Wikileaks e o controle do espaço informacional”. Contemporanea (UFBA. Online). (2011). V. 9, p. 22-37.

FIRMINO, R.; KANASHIRO, M.; BRUNO F.; EVANGELISTA, R.; NASCIMENTO, L. "Fear, Security, and the Spread of CCTV in Brazilian Cities: Legislation, Debate, and the Market”. Journal of Urban Technology. 20 (2013) p. 65-84.

; DUARTE, F. - "Do mundo codificado ao espaço ampliado". In RHEINGANTZ, Paulo Afonso; PEDRO, Rosa (orgs.) - Qualidade do lugar e cultura contemporânea: controvérsias e ressonâncias em ambientes urbanos. Rio de Janeiro: UFRJ, 2012. p. 69-80. 
; DUARTE, F. - "Private video monitoring of public spaces: the construction of new invisible territories". In The 6th Biannual conference of the Surveillance Studies Network Surveillance: Ambiguities and Asymmetries. Barcelona: Universidad de Barcelona/SSN, 2014.

FRIEDMANN, J. - "Reflections on Place and Place-making in the Cities of China". International Journal of Urban and Regional Research. (2007) V. 31, n.2, p. 257-279.

GOTTMANN, J. - The Significance of Territory. Virginia: University Press of Virginia, 1973.

HAESBAERT, R. - O mito da desterritorialização. Do "fim dos territórios" à Multiterritorialidade. Rio de Janeiro: Bertrand Brasil, 2004.

HAFTING, T.; FYHN, M.; MOSER, May-Britt; MOSER, E. - "Microstructure of a spatial map in the entorhinal cortex". Nature. 436 (2005) p. 801-806.

LEMOS, A. - "Espaço, mídialocativa e teoriaAtor-Rede". Galáxia. Revista do Programa de Pós-Graduação em Comunicação e Semiótica. PUC-SP. ISSN 1982-2553. V. 13, n. 25 (jun, 2013) p. 52-65.

- "Mídia Locativa e Vigilância. Sujeito Inseguro, Bolhas Digitais, Paredes Virtuais e Territórios Informacionais”. In BRUNO, F., KANASHIRO, M., FIRMINO, R. - Vigilancia e visibilidade - Espaço, tecnologia e identificação. Porto Alegre: Ed. Sulina, 2010.

- "Post-Mass Media Functions, Locative Media, and Informational Territories: New Ways of Thinking About Territory, Place, and Mobility in Contemporary Society". Space and Culture. Sage Publications. [Em linha]. 13(4). (November 2010). p. 403-420. doi: $10.1177 / 1206331210374144$.

- "Mídia Locativa e Território Informacional". In ARANTES, P., SANTAELLA, L. (org.) - Estéticas Tecnológicas. Novos Modos de Sentir. São Paulo: EDUC, 2008.

- "Cidade e Mobilidade. Telefones Celulares, funçôes pós-massivas e territórios informacionais". Matrizes, Revista do Programa de Pós-Graduação em Ciências da Comunicação. São Paulo: USP. ISSN 1982-2073. Ano 1, N. ${ }^{\circ} 1$ (2007) p. 121-137.

MASSEY, D. - For space. London: Sage, 2005.

O'KEEFE, J. - "A review of the hippocampal place cells". Progress in Neurobiology. V.13 (1979) p. 419-439.

PRED, A. - "Place as Historically Contingent Process: Structuration and the Time-Geography of Becoming Place". Annals of the Association of American Geographers. 74:2 (1984) p. 279-297.

RAFFESTIN, C. - "Repères pour une théorie de la territorialité humaine". In DUPUY, G (dir) - Réseaux Territoriaux. Caen: Paradigme, 1988.

RELPH, E. - Place and Placelessness. London: Pion, 1976.

SACK, R. - Human Territoriality: Its theory and History. Cambridge: Cambridge University Press, 1986.

- "The Power of Place and Space”. Geographical Review. V. 83, n.3 (1993) p. 326-329.

SANTOS, M. - Espaço e método. Sáo Paulo: Nobel, 1992.

TUAN, Yi-Fu. - Topofilia: um estudo da percepção, atitudes e valores do meio-ambiente. São Paulo: Difel, 1980.

- Space and Place. The Perspective of Experience. Minneapolis, London: University of Minnesota Press, 2003.

SHIRVANEE, L. - "Locative Viscosity: Traces of social histories in public space". Leornardo, Electronic Almanac., Vol. 14, n. 3 (July, 2006) Disponível em WWW: <URL: http:// leoalmanac.org/journal/Vol_14/lea_v14_n03-04/lshirvanee.asp> 